\title{
Hydration in Children
}

\section{School Programs in Austria: A Combined Behavioral and Environmental Intervention to Promote Healthy Hydration}

\author{
Manuel Schätzer ${ }^{a} \quad J u l i a$ Schätzer ${ }^{a} \quad$ Friedrich Hoppichler ${ }^{a}$ b \\ a Special Institute for Preventive Cardiology and Nutrition, Salzburg, Austria; bivision of Internal Medicine, \\ Krankenhaus der Barmherzigen Brüder Salzburg, Salzburg, Austria
}

\section{Keywords}

School · Behavioral · Intervention · Nutrition · Hydration

\begin{abstract}
Founded in 2005, the Austrian Special Institute for Preventive Cardiology and Nutrition (SIPCAN) has established the goal of improving nutrition education, behavior, and environment (e.g., beverages offered at vending machines). Due to the existing infrastructure, school staff, facilities, policies, and environments, the school setting provides a logical choice as a context for implementing interventions to promote healthy hydration practices. Thus SIPCAN specializes in developing and implementing school programs focusing on the target group of 10-18-year-old pupils. The education is delivered by an on-staff teacher with whom the school children are familiar, and it is aimed to reach the school children's parents, to reinforce healthier hydration in the home environment. Therefore, no specially trained professionals are required. Additionally, such interventions require a minimum of money, effort, school time, and contain practical lessons regarding healthy nutrition and physical activity. Using achievable goals, the food and drink offered in school cafeterias and vending machines is changed, in a way that the target group is reached in the best possible way and the
\end{abstract}

healthier choice clearly becomes the easier choice. Last year, every third school of the target group attended at least one of these programs. In the school year of 2017/18, SIPCAN influenced 153,000 students ( $21 \%$ of the target group) through various health promoting programs.

(c) 2019 The Author(s)

Published by S. Karger AG, Basel

\section{Introduction}

A considerable increase in the prevalence of overweight and obesity has been observed. The WHO estimates that worldwide 340 million of the 5- to 19-yearolds are overweight or obese [1]. In Austria, 17\% of the 7 - to 14 -year-old boys and $16 \%$ of the girls are overweight and $9 \%$ of the 7 - to 14 -year-old boys and $6 \%$ of the girls are obese [2]. In addition to numerous physical implications (i.e., high blood pressure, elevated triglycerides, reduced HDL) [3], childhood obesity is associated with an increased cardiovascular mortality in adulthood [4]. At the same time, the impairment of physical activity, quality of life, and mental health increase [5]. Recent evidence suggests that the intake of sugar-sweetened beverages has a strong impact on the development of overweight and

\begin{tabular}{|c|c|}
\hline KARGER & $\begin{array}{l}\text { (c) } 2019 \text { The Author(s) } \\
\text { Published by S. Karger AG, Basel }\end{array}$ \\
\hline $\begin{array}{l}\text { E-Mail karger@karger.com } \\
\text { www.karger.com/anm }\end{array}$ & $\begin{array}{l}\text { This article is licensed under the Creative Commons Attribution- } \\
\text { NonCommercial-NoDerivatives } 4.0 \text { International License (CC BY- } \\
\text { NC-ND) (http://www.karger.com/Services/OpenAccessLicense). } \\
\text { Usage and distribution for commercial purposes as well as any dis- } \\
\text { tribution of modified material requires written permission. }\end{array}$ \\
\hline
\end{tabular}

\section{KARGER}


obesity in children and adults $[6,7]$. However, fluid intake in schoolchildren is a cause for concern in many countries. Studies show that approximately $60 \%$ of children do not consume enough fluids for breakfast and consequently arrive at school with a hydration deficit [811]. This is especially concerning because an unpublished study by Special Institute for Preventive Cardiology And Nutrition (SIPCAN) showed that $16 \%$ of over 600 Austrian school children never drink anything at school [12].

\section{The School as a Place for Implementing Measures}

It has long been known that the promotion of healthy eating and drinking behavior in children has a positive effect on the development of noncommunicable chronic diseases in childhood and adulthood, such as obesity, diabetes mellitus, hypertension, cardiovascular diseases, as well as various types of cancer and caries $[13,14]$. It is therefore obvious that health promotion should play an important role in childhood. In terms of infrastructure, staff, and many other factors, schools are a logical choice for the implementation of health promotion measures. However, schools differ in their structural conditions, the care structure, the school environment, and the availability of supermarkets and bakeries in the immediate school surroundings. On the other hand, each school exhibits individual internal dynamics resulting from the relationship between the school principal, parents, teachers, and children. It is postulated that lifestyle interventions can reduce the risk of obesity if they are incorporated into the curriculum [15]. In addition, the school environment has a significant influence on eating and drinking behavior, as schoolchildren spend a significant part of the day and eat a large proportion of daily food intake in the school setting $[16,17]$. It has been shown several times that school-based prevention programs can be effective in reducing overweight and obesity in children $[18,19]$.

\section{New Paths for Healthy Hydration at Schools}

Conventional health promotion in the school setting usually involves external experts coming to the school to work with pupils. Workshops are held at schools, school representatives are invited to training courses, and parent lectures are offered. Often bans are imposed (e.g., sales bans at school cafeterias), and external experts decide what is suitable for the target group. School staff such as teachers and school counselors - the actual caregivers - often become extras. The problem with the use of external experts is that this is personnel- and costintensive and requires comprehensive appointment coordination. The sustainability of such interventions is often questionable.

In contrast, SIPCAN has been offering successful prevention programs beyond conventional health promotion with a focus on healthy hydration at school settings in Austria since 2005. The cooperation with over 1,000 schools throughout Austria has resulted in a wealth of experience, from which the following central points for implementable access to health promotion in schools can be derived.

\section{Use of Internal Resources}

As already mentioned, health promotion programs are often cost-intensive and linked to school-external experts. Our many years of experience in the school setting have shown that it is sensible to offer programs in which on-staff teachers are supported in such a way that healthpromoting content is readily implemented by all target groups with measurable, long-term success. One example is the SIPCAN school program "Healthy Snack and Smart Hydration Specialist”. Developed in 2009, this pilot study founded by a national grant has been offered yearly since the school year of 2012-2013. This program is an innovative module set for the school subject "Biology and Environmental Sciences" in the 5th grade, in which nutritional knowledge is taught in an experience- and practiceoriented way, showing pupils the importance of a healthy diet and school snack. The contents of these curricula increase the direct benefit for the school and the teachers. For 5 weeks, teachers work through one module per week with the pupils. Parallel to the lessons, the pupils observe their nutritional behavior over a period of 4 weeks with the help of a snack diary. This encourages learning through self-awareness.

In addition, parents are informed weekly in order to ensure transfer of learned concepts into their home environment and to give parents the opportunity to support their children. The 5th module is followed by a theoretical and practical exam (in the form of a multiple-choice test and the last week of the 4-week self-observation phase with the snack diary). With a positive result, the pupils are presented with a Healthy Snack and Smart Hydration Specialist Award. Additionally, all modules contain exercise impulses for the pupils. Also included is an additional module for "Physical Education" in which the learned contents are 
linked to an activity game. The feedback of teachers shows that this concept is received very positively: $96 \%$ of teachers would recommend participation to colleagues and 92\% would participate again themselves. It is also interesting to note that about $70 \%$ of parents and approximately $11 \%$ of all pupils in the 5 th grade are currently participating.

\section{Attainability of Objectives}

Very often goals in health promotion are difficult to attain. For example, the WHO recommends an intake of free sugars of $<10 \%$ of total energy intake [20]. Only $11 \%$ of women and $19 \%$ of men in Austria reach this recommendation [21]. This raises the question of how target groups can be reached in such a way that these recommendations can be perceived as achievable goals. SIPCAN developed - with regard to the sugar content of beverages - a unique practice-oriented method that has turned into a success story in recent years. Derived from the abovementioned WHO recommendation that $<10 \%$ of the daily energy intake should be consumed from added sugars (e.g., sucrose, glucose, fructose, as well as sugar in honey and fruit juices), we developed a simple orientation criterion for beverages in coordination with a scientific expert committee in 2008. Considering the recommendations for children, this $10 \%$ of the $2,450 \mathrm{kcal}$ daily energy intake (guideline for the average daily energy intake for 13- to 14-year-old boys and girls [22]) amounts to approximately $60 \mathrm{~g}$ of free sugars per day. Under the further stipulation that a half liter drink (usual container size) should not exceed half of this daily upper limit, this results in a value of $30 \mathrm{~g}$ of free sugars per 500 mland corresponds to a value of $6 \mathrm{~g}$ sugar per $100 \mathrm{~mL}$. Taking into account the average sugar content in beverages at the time of the introduction of the orientation, this value of $6 \mathrm{~g}$ per $100 \mathrm{~mL}$ was deemed too low. Therefore, a tolerance range of $25 \%$ was added. Thus, a value of $7.4 \mathrm{~g}$ sugar per $100 \mathrm{~mL}$ was introduced as orientation criterion; this turned out to be a clearly achievable goal for both consumers and industry. In addition, another orientation criterion stated that no sweeteners may be added to a beverage. Adding sweeteners is controversial because consumers have no chance to accommodate to a less sweet taste [23], and the use of sweeteners is questionable for health reasons [24].

These orientation criteria were established in coordination with the Austrian Ministries of Health and Education as a guideline for the sale of beverages at schools. This applies to all areas of school catering including the school cafeteria [25] and vending machines [26].

School Programs in Austria: A Combined

Behavioral and Environmental
Since 2010, SIPCAN has been collecting data on the sugar content in beverages annually as part of a nationwide research project and publishes the results in the socalled "SIPCAN Beverage List." Thus, the sugar content of beverages can be compared, and the decision to consume a less sugary drink is promoted. Through the broad use of the beverage list as a basis for decision-making in the school sector, we are able to create an incentive for beverage producers to reduce their sugar content. As a result, Austrian industry began to gradually adjust the sugar content of beverages to the criteria. The average sugar content at the first monitoring in 2010 was $7.53 \mathrm{~g}$ $( \pm 2.86)$ per $100 \mathrm{~mL}$. In 2017, this value was $6.75( \pm 2.79)$ g per $100 \mathrm{~mL}$, corresponding to a reduction of $13 \%$ [24].

This sugar reduction in schools thus became a nationwide public health strategy. It was decided to further reduce the value of the sugar content from 7.4 to $6.7 \mathrm{~g}$ per $100 \mathrm{~mL}$ by September 2019. This was again coordinated with the Ministries of Health and Education and applied to all schools in Austria. Without the formulation of an attainable goal, this development would not have been possible and a change of this magnitude would very probably not have taken place.

\section{Reaching Target Groups}

With regard to the design of health-promoting catering conditions, schools represent a unique opportunity to reach and direct children and young people in a skillful and goal-oriented manner. A practical example of this is the design of beverage vending machines. According to a yet unpublished study by SIPCAN, 66\% of all secondary schools in Austria have at least one vending machine. At the same time, there is direct competition from supermarkets and snack stands in the immediate vicinity of the school. In our experience, there is a very good chance that pupils will buy their beverages outside the school if they do not find appealing beverages at the school, whereas at school, the sugar content and the container size can be regulated. In response, SIPCAN developed the "Beverage Vending Machine Check" and implements it nationwide at $>200$ school locations. Instead of bans, an $80: 20$ rule is applied to vending machines. This means that at least $80 \%$ of the offering must correspond to the criteria for beverages (maximum of $7.4 \mathrm{~g}$ sugar/ $100 \mathrm{~mL}$ and no sweeteners). Water and sparkling fruit juice must be included in the range as ideal thirst quenchers. In this way, it is possible to reach all target groups and prevent the pupils from leaving the school building. On the part of the im-

Ann Nutr Metab 2019;74(suppl 3):25-29 DOI: $10.1159 / 000500342$ 
plementation, the beverage vending machine check is carried out as a teleproject with a school staff member providing the SIPCAN employee with all the necessary information about the vending machines. The teleproject approach represents an innovative approach in the field of health promotion. It is very well received and it enables us to support schools throughout Austria in a targeted and cost-efficient manner.

\section{Making the Healthier Choice the Easier Choice}

In addition to influencing behavior, the design of healthpromoting catering plays a central role in schools. Without a change in the offerings at school cafeterias and vending machines, the pupils cannot implement the healthy eating knowledge they have learned, and in the worst case may be forced to eat an unhealthy diet. In addition to vending machines, school cafeterias offer a wide food assortment ranging from cold snacks to warm snacks and beverages. In 2007, SIPCAN began supervision of school cafeterias through the "School Cafeteria Check," a system in which each product group is classified and evaluated on the basis of 29 criteria. In addition to the design of the offerings, the presentation of goods also plays a decisive role. School cafeterias that meet $75 \%$ of all criteria receive an award. By this means, the healthier choice becomes the easier choice. SIPCAN currently supervises school cafeterias at 151 schools and reaches 100,000 pupils in that manner.

\section{Conclusion}

Health promotion programs should utilize internal school resources and provide as much support as possible to the targeted empowerment of teachers. It is important to formulate achievable goals that motivate all target groups. In this context, the school setting represents a unique opportunity because children spend most of the day in definable and controllable conditions. In order for measures to be implemented nationwide, the teleproject approach seems to be reasonable and successful. Complete module-sets and self-explaining materials represent a great added value for the teachers. Despite the great heterogeneity of the target group, it is also possible to reach the parents or guardians of children this way. As each school has its own dynamics, it makes the implementation of health promotion measures at schools particularly challenging and exciting. In order to achieve success in daily practice, however, it is necessary to adapt to each setting in the best possible way, to develop cost- and time-saving techniques, and employ a practical approach.

\section{Disclosure Statement}

M.S. received travel expenses and registration fee from Danone Research to attend the 2018 Hydration for Health Scientific Conference. J.S. and F.H. have no conflicts of interest to disclose.

\section{References}

1 WHO. Obesity and overweight. Geneva: WHO; 2018.

2 Elmadfa I, et al: Austrian Nutrition Survey 2012. Available from: https://ernaehrungsbericht.univie.ac.at/fileadmin/user_upload/ dep_ernaehrung/forschung/ernaehrungsberichte/ernaehrungsbericht2017 web_20171018.pdf (accessed January 2019).

3 I'Allemand D, Wiegand S, Reinehr T, Müller J, Wabitsch M, Widhalm K, et al.; APV-Study Group. Cardiovascular risk in 26,008 European overweight children as established by a multicenter database. Obesity (Silver Spring). 2008 Jul;16(7):1672-9.

4 Twig G, Yaniv G, Levine H, Leiba A, Goldberger N, Derazne E, et al. Body-Mass Index in 2.3 Million Adolescents and Cardiovascular Death in Adulthood. N Engl J Med. 2016 Jun;374(25):2430-40.

5 Eschenbeck H, Kohlmann CW, Dudey S, Schurholz T. Physician-diagnosed obesity in German 6- to 14-year-olds. Prevalence and comorbidity of internalising disorders, exter- nalising disorders, and sleep disorders. Obes Facts. 2009;2(2):67-73.

6 Malik VS, Pan A, Willett WC, Hu FB. Sugarsweetened beverages and weight gain in children and adults: a systematic review and meta-analysis. Am J Clin Nutr. 2013 Oct;98(4): 1084-102.

7 Luger M, Lafontan M, Bes-Rastrollo M, Winzer E, Yumuk V, Farpour-Lambert N. SugarSweetened Beverages and Weight Gain in Children and Adults: A Systematic Review from 2013 to 2015 and a Comparison with Previous Studies. Obes Facts. 2017;10(6): 674-93.

8 Assael BM, Cipolli M, Meneghelli I, Passiu M, Cordioli S, Tridello G, et al. Italian Children Go to School with a Hydration Deficit. J Nutr Disord Ther. 2012;2(3):3.

9 Bonnet F, Lepicard EM, Cathrin L, Letellier C, Constant F, Hawili N, et al. French children start their school day with a hydration deficit. Ann Nutr Metab. 2012;60(4):25763.
10 Stookey JD, Brass B, Holliday A, Arieff A. What is the cell hydration status of healthy children in the USA? Preliminary data on urine osmolality and water intake. Public Health Nutr. 2012 Nov;15(11):2148-56.

11 Kaushik A, Mullee MA, Bryant TN, Hill CM. A study of the association between children's access to drinking water in primary schools and their fluid intake: can water be 'cool' in school? Child Care Health Dev. 2007 Jul; 33(4):409-15.

12 Luger M, Schmid M, Schätzer M, Winzer E, Rust $\mathrm{P}$. Habitual intake of breakfast in relation to overweight status among Viennese preadolescents. In: 21. wissenschaftliche Tagung der Österreichischen Gesellschaft für Public Health (ÖGPH). Vienna, Austria; 2018. Abstract-Band: 151.

13 Lobstein T, Baur L, Uauy R; IASO International Obesity TaskForce. Obesity in children and young people: a crisis in public health. Obes Rev. 2004 May;5(1 Suppl 1):4104. 
14 Janssen I, Katzmarzyk PT, Srinivasan SR, Chen W, Malina RM, Bouchard C, et al. Combined influence of body mass index and waist circumference on coronary artery disease risk factors among children and adolescents. Pediatrics. 2005 Jun;115(6):162330.

15 Waters E, de Silva-Sanigorski A, Hall BJ, Brown T, Campbell KJ, Gao Y, et al. Interventions for preventing obesity in children. $\mathrm{Co}_{-}$ chrane Database Syst Rev. 2011 Dec;(12): CD001871.

16 Wang D, Stewart D. The implementation and effectiveness of school-based nutrition promotion programmes using a health-promoting schools approach: a systematic review. Public Health Nutr. 2013 Jun;16(6):1082100.

17 Derry K. Healthy young children: encouraging good nutrition and physical fitness. Young Child. 2006;61:10-1.

18 Kropski JA, Keckley PH, Jensen GL. Schoolbased obesity prevention programs: an evi- dence-based review. Obesity (Silver Spring). 2008 May; 16(5):1009-18.

19 Wang Y, Cai L, Wu Y, Wilson RF, Weston C, Fawole $\mathrm{O}$, et al. What childhood obesity prevention programmes work? A systematic review and meta-analysis. Obes Rev. 2015 Jul; 16(7):547-65.

20 WHO. Guidline: Sugars intake for adults and children. Geneva, WHO, 2015. Available from: https://www.who.int/nutrition/publications/guidelines/sugars_intake/en/ (accessed January 2019).

21 Rust P, Hasenegger V, König J. Austrian Nutrition Survey 2017. Available from: https:// ernaehrungsbericht.univie.ac.at/fileadmin/ user_upload/dep_ernaehrung/forschung/ernaehrungsberichte/oesterr_ernaehrungsbericht_2012.pdf (accessed January 2019).

22 German Nutrition Society, Austrian Nutrition Society, Society for Nutrition Research, Swiss Nutrition Association: Referenzwerte für die Nährstoffzufuhr, ed 1. Frankfurt am Main, Umschau Braus, 2008.
23 Austrian Nutrition Society: Sweeteners. 2014. Available from: http://www.oege.at/index. php/bildung-information/ernaehrung-vona-z/54-bildung-information/ernaehrungvon-a-z/1784-suessstoffe (accessed January 2019).

24 Luger M, Winzer E, Schätzer M, Dämon S, Moser N, Blagusz K, et al. Gradual reduction of free sugars in beverages on sale by implementing the beverage checklist as a public health strategy. Eur J Public Health. 2018 Oct; 28(5):961-7.

25 Ministery for Women and Health. Guideline school. 2015. Available from: https://www. bmgf.gv.at/cms/home/attachments/6/4/0/ CH1047/CMS1313558884746/leitlinie_ schulbuffet_20150619.pdf (accessed January 2019).

26 SIPCAN. Guidelines for vending machines. 2018. Available from: https://www.sipcan.at/ uploads/2/8/1/4/28145439/sipcan_leitfaden getr\%C3\%A4nkeautomat_20180129.pdf (accessed January 2019). 